Indexed by:

Csinta

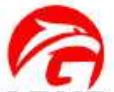

GARUDA

Crossref

crossmark

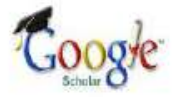

Dimensions

on

\title{
KOMPARASI PENGARUH HUBUNGAN KETERIKATAN TEMPAT DAN CITRA TEMPAT KETIGA TERHADAP DESAIN KAFE
}

\author{
Muhammad Barkah \\ Institut Teknologi Bandung, \\ Bandung, Indonesia \\ Jalan Ganeca No. 10, Lb. Siliwangi, \\ Kecamatan Coblong, Bandung, \\ Indonesia
}

Agus S. Ekomadyo

Institut Teknologi Bandung, Bandung, Indonesia

Jalan Ganeca No. 10, Lb. Siliwangi

Kecamatan Coblong, Bandung,

Indonesia

\author{
Krisna Agustriana \\ Institut Teknologi Bandung, \\ Bandung, Indonesia \\ Jalan Ganeca No. 10, Lb. Siliwangi \\ Kecamatan Coblong, Bandung, Indonesia
}

\author{
Shania Adhalia Sharif \\ Institut Teknologi Bandung, \\ Bandung, Indonesia \\ Jalan Ganeca No. 10, Lb. Siliwangi, \\ Kecamatan Coblong, Bandung, \\ Indonesia
}

\section{Vanesa Susanto \\ Institut Teknologi Bandung, Bandung, Indonesia Jalan Ganeca No. 10, Lb. Siliwangi, Kecamatan Coblong, Bandung, Indonesia}

Manuscripts screening tools:

turnitin

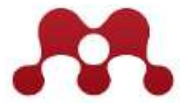

MENDELEY

G grammarly
Key words:

Imagery of third place; place attachment; reciprocal relationship; design aspects

Doi:

10.17509/jaz.v4i1.29926

Cite article:

Barkah, M., Agustriana, K., Sharif, S. A., Ekomadyo, A. S., dan Susanto, V. (2021). Komparasi Pengaruh Hubungan Keterikatan Tempat dan Citra Tempat Ketiga terhadap Desain Kafe. Jurnal Arsitektur Zonasi, 4(1), 8-20. https://doi.org/doi.org/10.17509/jaz.v4i1.29926

Akses online:

untuk naskah lengkap tersedia di: https://ejournal.upi.edu/index.php/jaz/issue/archive 


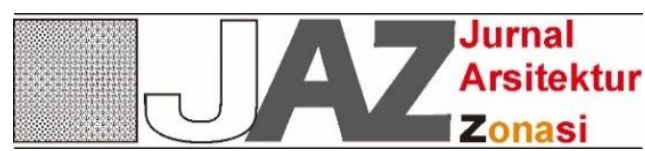

http://ejournal.upi.edu/index.php/jaz - e-mail:_jurnal_zonasi@upi.edu doi.org/10.17509/jaz.v4i1.29926

\section{Komparasi Pengaruh Hubungan Keterikatan Tempat dan Citra Tempat Ketiga terhadap Desain Kafe}

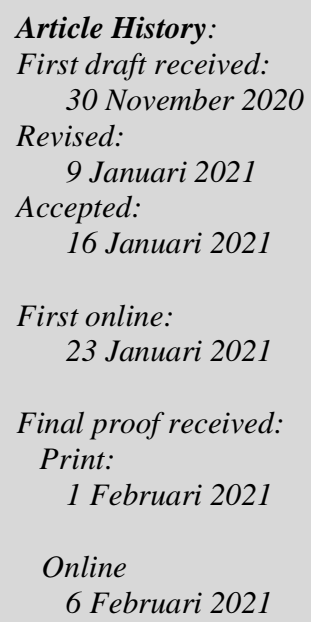

Jurnal Arsitektur ZONASI is indexed and listed in several databases:

\section{SINTA 4 (Arjuna)}

GARUDA (Garda Rujukan Digital) Google Scholar

Dimensions

oneSearch

BASE

\section{Member: \\ Crossref \\ RJI}

APTARI

FJA (Forum Jurna Arsitektur) IAI AJPKM

\author{
Muhammad Barkah ${ }^{1}$ \\ Krisna Agustriana ${ }^{2}$ \\ Shania Adhalia Sharif ${ }^{3}$ \\ Agus S. Ekomadyo ${ }^{4}$ \\ Vanesa Susanto ${ }^{5}$ \\ 1,2,3,4,5 Institut Teknologi Bandung, Bandung, Indonesia \\ Jalan Ganeca No. 10, Lb. Siliwangi, Kecamatan Coblong, Bandung, Indonesia \\ Email: barkahhas@gmail.com ; krisagtrian@gmail.com ; shania.sharif02@gmail.com ; \\ aekomadyo00@gmail.com ; vanessa.susanto911@gmail.com
}

\section{Abstract:}

Cafes and coffee shops in Indonesia are experiencing significant growth. The number of outlets and domestic coffee consumption increased rapidly in the past three years. The interactions between cafe and its patrons can create the feeling of place attachment so that cafes are able to be third place. Cafes as third place are able to give a good impact to improve the quality of patrons' lives and their surroundings. The research methodology is quantitative by questionnaires and qualitative by observation and interviews. The determination of the cafe as an object of the research is based on the principle of contradiction. Cafes are located in a quiet and crowded neighbourhood. The purpose of this study was to examine the implications of the relationship between place attachment and the imagery of third place on the design. The relationship between place attachment to the imagery of the cafe as a third place is reciprocal. The higher the value of place attachment, the better the cafe's imagery as a third place. Comparison of the influence of the relationship between place attachment and third place imagery on cafe design can be seen from the aspects of circulation, floor plan, spatial patterns, accessibility, accommodation, universality, and impressions.

Keywords: Imagery of third place; place attachment; reciprocal relationship; design aspects.

Abstrak:

Kedai kopi/kafe di Indonesia mengalami pertumbuhan yang signifikan. Jumlah gerai dan konsumsi domestik kopi meningkat dalam kurun waktu tiga tahun. Interaksi antara kafe dan konsumen dapat menimbulkan rasa keterikatan tempat sehingga kafe mampu memiliki citra tempat ketiga. Kafe sebagai tempat ketiga dapat memberikan dampak yang baik terhadap peningkatan kualitas hidup pelanggan dan lingkungan sekitarnya. Tujuan penelitian ini adalah meninjau implikasi hubungan keterikatan tempat dan citra tempat ketiga terhadap desain. Metodologi penelitian adalah kuantitatif dengan sebaran kuesioner dan kualitatif dengan observasi serta wawancara. Penentuan kafe sebagai objek penelitian berdasarkan asas kontradiksi. Kafe berada di lingkungan yang padat dan lengang. Hubungan antara keterikatan tempat dengan citra kafe sebagai tempat ketiga adalah timbal balik. Semakin tinggi rasa keterikatan tempat, maka semakin baik citra kafe sebagai tempat ketiga. Perbandingan pengaruh hubungan keterikatan tempat dan citra tempat ketiga terhadap desain kafe dapat ditinjau dari aspek sirkulasi, denah, pola ruang, aksesibilitas, akomodasi, universalitas, dan impresi.

Kata Kunci: Citra tempat ketiga; keterikatan tempat; hubungan timbal balik; aspek desain.

\section{Pendahuluan}

Kedai kopi di Indonesia mengalami pertumbuhan yang signifikan. Hal ini ditandai dengan meningkatnya jumlah gerai dan konsumsi domestik kopi (Hariyanto, 2019). Asosiasi Eksportir Kopi Indonesia (AEKI) mencatat daya serap bisnis ini sebanyak 25\% atau sekitar 90.000-95.000 ton kopi dari total produksi 
kopi untuk dalam negeri. Selain itu, pertumbuhan bisnis kedai kopi di Indonesia hampir mencapai angka 20\% dalam kurun waktu 3 tahun (Zuhriyah, 2019). Jumlah kedai kopi meningkat hampir 2.000 gerai sepanjang tahun 2016-2019 (Sugianto, 2019). Angka yang diterbitkan oleh majalah MIX Marcomm yang didukung oleh TOFFIN, perusahaan penyedia solusi bisnis HORECA (hotel, restaurant, cafe), hanya mencakup jaringan gerai di kota-kota besar. Jumlah riil gerai bisa lebih banyak jika kedai-kedai kopi independen modern dan tradisional dilibatkan dalam perhitungan. Bisnis kedai kopi atau kafe memiliki prospek yang menjanjikan dewasa ini. Pertumbuhan usaha kafe yang pesat disebabkan oleh beberapa faktor. Kafe berkembang dari tradisi warung kopi, tempat orang singgah dan bersosialisasi seraya mengopi (Putra \& Ekomadyo, 2015). Budaya ini umumnya berasal dari generasi Y dan berlanjut ke generasi Milenial (Susanto et al., 2020). Kafe dapat menjadi alternatif tempat untuk menetap sementara waktu dan memberikan suasana baru dari sela rutinitas kehidupan sehari-hari. Di beberapa kota, kafe menjadi sarana untuk membangun komunitas kreatif (Agus S. Ekomadyo, 2020; Agus S. Ekomadyo et al., 2018; Robbany et al., 2020).

Bangunan tempat singgah sementara waktu yang berada di antara tempat bekerja dan bermukim disebut sebagai tempat ketiga (third place)(Oldenburg, 1999). Dengan konsep tempat ketiga, maka suatu bangunan bisa menjadi tempat untuk berkumpul, bersosialisasi, dan membangun komunitas (Yuwono \& Ekomadyo, 2018). Tjora dan Scambler (2013) mengungkapkan bahwa kafe sebagai tempat ketiga dapat memberikan dampak yang baik terhadap peningkatan kualitas hidup pelanggan dan lingkungan sekitarnya. Kafe dapat menjadi tempat berkumpul masyarakat setempat dan sekitarnya. Kafe juga dapat menjadi ruang bercengkerama dan menghabiskan waktu bersama orang-orang terdekat sehingga memberikan kesenangan dan kebahagiaan. Selain itu, kafe dapat menjadi wadah suatu komunitas berbagi pandangan dan pengetahuan.

Interaksi antara konsumen dengan kafe/kedai kopi dapat menimbulkan rasa keterikatan tempat (place attachment). Indikator keterikatan tempat ditandai dengan pengguna mengalami relasi emosional dan pemaknaan ruang. Hal ini akan berpengaruh terhadap pembentukan citra tempat. Dalam keterikatan tempat pada kafe, citra ini ditunjukkan oleh aktivitas sosial yang diwadahi dalam fasilitas rancangan. Desain yang baik adalah desain yang mampu memberikan pengaruh terhadap pemaknaan ruang bagi pengguna sehingga tercipta citra yang diharapkan sebagai tujuan mengapa fasilitas tersebut dirancang.

Studi ini bertujuan untuk meninjau implikasi hubungan keterikatan tempat dan citra tempat ketiga terhadap desain dengan cara membandingkan objek penelitian. Adapun rumusan masalah penelitian ini sebagai berikut.
1. Apa citra yang dihasilkan oleh masing-masing kafe sebagai tempat ketiga?
2. Bagaimana keterikatan tempat memengaruhi pengguna masing-masing kafe?
3. Bagaimana pengaruh hubungan keterikatan tempat dan citra tempat ketiga terhadap desain kafe?

\section{Landasan Teori}

Teori tempat ketiga merupakan teori yang telah banyak dikaji oleh ahli. Menurut Oldenburg (1999), third place atau tempat ketiga adalah tempat-tempat selain rumah dan tempat bekerja di mana masyarakat membentuk komunitas dan menghabiskan waktu di komunitas-komunitas tersebut. Tempat ketiga(Permana, 2012) merupakan tempat yang penting untuk meningkatkan kesejahteraan hidup masyarakat. Menurut Oldenburg, terdapat delapan ciri-ciri dari tempat ketiga. Pertama, daerah netral (neutral ground); di mana pengunjung dapat datang dan pergi sesukanya tanpa harus bertindak sebagai tuan rumah. Kedua, menyamaratakan tingkat sosial atau medan permainan level sosial bagi peserta (a social leveler or a levelplaying field for participants), di mana pengunjung dapat datang dan berinteraksi dengan bebas. Selain itu, tempat ketiga juga mendorong individu untuk memperluas lingkaran sosialnya. Ketiga, percakapan (conversation); percakapan atau interaksi sosial adalah aktivitas utama dari tempat ketiga. Keempat, aksesibilitas dan akomodasi yang baik (good accessibility and accommodation); lokasi tempat ketiga harus mudah diakses serta dapat mengakomodasi kebutuhan pengunjung. Kelima, pelanggan tetap (the regulars); tempat ketiga memiliki pelanggan tetap yang membantu menciptakan karakter tempat sehingga dapat menarik lebih banyak pengunjung. Keenam, profil rendah ( a low profile); tempat ketiga memiliki kesan sederhana yang dapat menerima segala tipe pengunjung. Ketujuh, suasana yang menyenangkan (playful mood); suasana percakapan pada tempat ketiga harus menyenangkan dan tidak pernah tegang. Terakhir, rumah kedua (a home away from home), pengunjung merasakan kenyamanan psikologis yang serupa dengan berada di rumah, pengunjung merasakan kehangatan dan merasa dirinya terikat pada tempat tersebut.

Menurut (Tjora \& Scambler, 2013), sebagian besar tempat ketiga adalah tempat-tempat usaha yang menyediakan makanan dan/atau minuman kepada pelanggan dalam kegiatan sehari-hari, seperti kafe. Begitu juga menurut banyak orang, kedai kopi berfungsi sebagai tempat ketiga, tempat rutin berinteraksi dengan sesama anggota komunitas. Di Amerika Serikat, dari tahun 2000 hingga 2004, bisnis makanan cepat saji 
tumbuh pada tingkat $2 \%$ per tahun, sementara bisnis kedai kopi tumbuh lebih dari 10\% setiap tahun (Holmes, 2004). Tempat ketiga terbentuk saat berbagai individu dari berbagai latar belakang kehidupan mengunjungi tempat-tempat tersebut untuk menikmati kehadiran satu sama lain. Individu-individu ini akan menjadi pelanggan tetap yang dapat membentuk suasana dan karakter dari tempat ketiga tersebut. Dalam era globalisasi, tempat ketiga tetap menjadi tempat untuk berkontemplasi dan bertemu dengan orang-orang untuk pekerjaan maupun aktivitas lainnya (Lukito \& Xenia, 2018). Untuk beberapa orang, tempat ketiga dapat memberikan dukungan psikologis lebih daripada rumah. Konsep rumah dan kenyamanan bergantung terhadap pengalaman personal, latar belakang budaya, dan kelas sosial (Rosenbaum et al., 2007).

Menurut Tjora et al. (2013), terdapat sepuluh ciri-ciri kafe sebagai tempat ketiga. Pertama, menyatukan lingkungan (unify the neighborhood); kafe merupakan tempat-tempat kecil yang mampu menyatukan masyarakat. Kafe menjadi tempat berkumpul bagi masyarakat lokal untuk saling mengenal dirinya dan orang disekitarnya, yang kemudian akan menjadi asal muasal terbentuknya komunitas. Kedua, (friends by the set); kafe menjadi tempat untuk bergaul dengan teman-teman yang dapat menawarkan kepuasan tanpa adanya konflik. Ketiga, suka cita persahabatan (the joys of camaraderie); kafe menjadi ramai dan penuh dengan kehidupan di saat semua anggota komunitasnya berkumpul. Kafe tidak lagi menjadi tempat yang tenang dan damai dan menjadi tempat di mana banyak tawa yang terdengar. Keempat, forum intelektual (an intellectual forum); kafe sebagai tempat berkolaborasi untuk mendapatkan gagasan yang inovatif. Kelima, gerbang masuk ( a port of entry); kafe menjadi fasilitas untuk berkenalan bagi pendatang baru dengan penghuni lama dari suatu komplek perumahan atau kawasan tempat tinggal. Keenam, area pementasan (a staging area); kafe sebagai tempat bertemu antara penghuni suatu kawasan area tempat tinggal. Ketujuh, pembentuk modal sosial (generating social capital); kafe sebagai tempat pembentuk modal sosial (social capital) atau ikatan yang terbentuk diantara masyarakat dalam suatu daerah. Semakin kuat dan besar jumlah modal sosial yang ada, daerah tersebut akan memiliki tingkat ekonomi yang semakin baik juga. Kedelapan, komunitas yang saling bantu-membantu (mutual aid societies); kafe sebagai tempat untuk saling membantu satu sama lain. Saat sebuah komunitas sedang berkumpul, anggota yang memiliki masalah apapun biasanya akan menuangkan masalah yang sedang dihadapinya kepada komunitasnya. Hal ini dikarenakan setiap anggota komunitas masing-masing memiliki kenalan dari berbagai latar belakang pendidikan dan pekerjaan sehingga bisa saling bantu-membantu. Kesembilan, memberi kehidupan pada kawasan publik (adding life to the public domain); kafe menjadi penghidupan kembali suasana ruang publik yang tidak ramah kepada pengguna jalan akibat perkembangan kota yang lebih fokus kepada kendaraan. Kafe-kafe pinggir jalan dapat memanusiakan suatu daerah, mengurangi kriminalitas, dan menambah nilai ekonomi sekitarnya. Terakhir, berkontribusi kepada demokrasi (the contribution to democracy); kafe menjadi tempat berdiskusi berbagai pandangan dan pengalaman, sehingga dapat memperluas wawasan komunitasnya terhadap hal-hal yang terjadi di sekitarnya tanpa prasangka maupun keberpihakan.

Seperti yang dapat dilihat pada indikator dan pengertian yang telah dijelaskan, dapat terlihat bahwa kafe sebagai tempat ketiga memiliki indikator yang cukup luas dan abstrak. Maka, untuk dapat menilai kafe sebagai tempat ketiga, akan dilakukan melalui pendekatan teori place attachment atau keterikatan tempat. Menurut Low (1992) dalam Waxman (2006), keterikatan tempat adalah hubungan simbolik yang terbentuk dari individu yang memberikan makna emosional/afektif terhadap suatu ruang maupun kawasan, makna tersebut menjadi dasar dari pemahaman suatu individu maupun kelompok tentang hubungannya dengan lingkungan. Keterikatan tempat juga mengacu kepada ide di mana individu membentuk ikatan yang istimewa dengan suatu pengaturan khusus yang memegang makna yang lebih dalam kepada individu itu sendiri. Keterikatan tempat adalah ikatan emosional yang mendalam atau hubungan yang dikembangkan pada suatu tempat tertentu dari waktu ke waktu melalui interaksi positif yang diulang (Low \& Altman, 1992). Penelitian mengenai keterikatan tempat menemukan bahwa keterikatan seseorang terhadap suatu tempat terjadi melalui serangkaian fenomena yang saling berkaitan daripada fenomena tunggal (Low \& Altman, 1992). Sedangkan menurut (Stedman, 2002), keterikatan tempat terbentuk melalui pengalaman manusia dengan lanskap. Selain itu, interaksi sosial yang cukup baik antara pengunjung dengan karyawan kafe yang bersifat beragam dan unik dapat menciptakan memori kolektif maupun hubungan secara psikologis dengan pengguna lainnya (Sulistiani, 2018). Melalui memori, orang menciptakan makna sebuah tempat dan menghubungkannya dengan diri sendiri (Setiati et al., 2015). Seseorang memberikan arti pada suatu tempat dan menerima makna tempat sebagai imbalannya. Karakter suatu tempat diartikan oleh sudut pandang, sikap, keyakinan, simbol, dan mitos orangorang yang berada di tempat itu (Shamai, 1991). Seseorang yang menghabiskan dan berkomunikasi dalam waktu lebih lama dalam suatu tempat akan membuat keterikatan tempat dengan tempat tersebut (Hashemnezhad et al., 2013). 
Dalam penelitiannya, (Waxman, 2006) kemudian membentuk suatu model yang mengilustrasikan faktor yang hadir dalam keterikatan tempat pada kafe. Model tersebut membagi faktor-faktor tersebut ke dalam dua kategori, yaitu faktor fisik dan faktor sosial (Gambar 1). Model tersebut dapat dilihat pada diagram berikut.

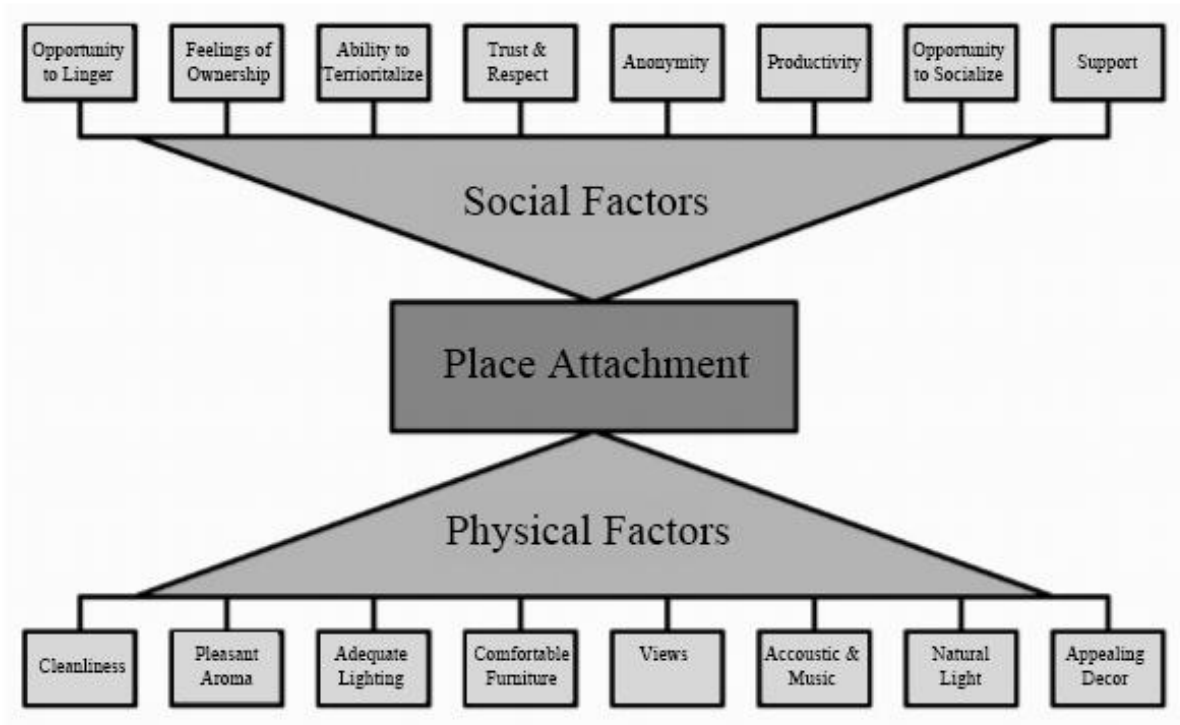

Gambar 1. Model faktor keterikatan tempat pada kafe.

(Diolah dari Waxman, 2006)

Faktor sosial yang mempengaruhi keterikatan tempat pada kafe adalah sebagai berikut. Pertama, kesempatan untuk berdiam lebih lama (opportunity to linger); kesempatan untuk berdiam lebih lama ditambah adanya pelanggan tetap sangat mempengaruhi iklim sosial dari cafe. Namun kesempatan untuk berdiam ini juga dipengaruhi dari interaksi sosial dengan manajemen kafe maupun kenyamanan fisik seperti tempat duduk atau suasana (musik, aroma, visual) yang nyaman. Kedua, rasa kepemilikan (feeling of ownership); pelanggan yang merasa sangat akrab dengan suatu kafe hingga menumbuhkan rasa kepemilikan terhadap kafe tersebut. Contoh sifat kepemilikan yang ditunjukkan pelanggan adalah memiliki tempat duduk favorit dan leluasa menggunakan fasilitas kafe. Ketiga, kepercayaan, rasa hormat, dan anonimitas (trust, respect and anonymity); ketika iklim kepercayaan dibangun pada kafe, orang-orang akan disambut dan dapat menjadi diri mereka sendiri. Selain itu dikarenakan kafe bukanlah tempat di mana peran dan identitas dibangun, sehingga kafe memungkinkan individu untuk memulai baru dengan identitas selain dari siapa diri mereka. Keempat, produktivitas dan pengembangan pribadi (productivity and personal growth); pada penelitian Waxman (2006), banyak pelanggan yang menjawab bahwa kafe adalah tempat yang mereka datangi jika ingin merasa produktif. Selain itu, bagi para remaja pergi ke kafe untuk menikmati minum kopi membuat mereka merasa dewasa serta memberikan kesempatan untuk pergi ke suatu tempat selain rumah dan merasakan otonomi yang lebih besar. Kelima, makhluk sosial dan orang asing yang dikenali (social beings and familiar strangers); keberadaan seseorang di dalam kafe memberikan validasi keberadaannya sebagai bagian dari komunitas. Banyak orang berdatangan ke kafe dalam grup maupun perorangan dengan tujuan untuk berinteraksi dengan orang-orang lainnya di dalam kafe. Dalam studi yang dilakukan oleh Waxman (2006) menyebutkan bahwa 38\% dari jumlah pengunjung total lebih senang untuk berada di dalam kafe dengan wajah-wajah yang akrab tanpa melakukan interaksi. Sehingga dalam hal tersebut desainer harus memahami dan mempertimbangkan karakter pengunjung yang hanya menyukai keberadaan pengunjung lainnya tanpa melakukan interaksi dengan mereka. Terakhir, dukungan (support); banyak orang-orang yang berdatangan ke kafe untuk mendapatkan dukungan kelompok dari kenalan mereka untuk meningkatkan kesejahteraan. Barista maupun staf kafe yang dalam kesehariannya menjadi bagian dari hidup pengunjung, secara tak langsung meningkatkan interaksi sosial dan kedekatan dengan mereka.

Sedangkan, faktor fisik yang memengaruhi keterikatan tempat pada kafe adalah cleanliness, aroma, adequate lighting, access to natural light, comfortable furniture, appealing views, appealing music, dan appealing decor. Kebersihan (cleanliness) masuk ke dalam faktor penting dan ideal dalam cafe. Walaupun secara umum kebersihan adalah tanggung jawab staff, namun perancang juga bertanggung jawab menentukan finishing yang mudah dibersihkan serta dapat mengkamuflasekan kotoran. Aroma merupakan faktor tertinggi dalam mendesain. Hal ini dikarenakan produk yang dijual berupa kopi dan roti-rotian, sehingga harus memikirkan desain ventilasi yang memungkinkan aroma produk bisa sampai ke jalan dan menarik calon pelanggan yang melewati kafe. Pencahayaan yang memadai (adequate lighting) merupakan poin terpenting 
ketiga dari desain kafe. Kafe telah menjadi tempat orang untuk bekerja, membaca, atau belajar, sehingga pencahayaan menjadi unsur yang penting pada kafe. Perancang memiliki tanggung jawab untuk menciptakan desain yang mampu memanfaatkan pencahayaan alami secara maksimal, finishing yang dapat memantulkan cahaya dengan baik, serta memberikan warna cahaya yang nyaman untuk mata. Furnitur yang nyaman (comfortable furniture) menjadi unsur yang tidak bisa disepelekan karena berpengaruh pada kesempatan untuk berdiam lebih lama. Pada penelitian Waxman (2006), banyak responden yang mengeluhkan pemilihan furnitur. Pengunjung cenderung menyukai tempat duduk yang empuk. Namun pengelola kafe juga tidak menginginkan pengunjung berdiam terlalu lama terutama pada jam sibuk, sehingga tempat duduk yang terpilih sebaiknya tidak terlalu nyaman. Pemandangan (view) maupun akses kepada unsur alam seperti pencahayaan alami, ruang luar, maupun kehadiran tanaman akan meningkatkan pengalaman ruang dari kafe. Musik dan unsur dekorasi merupakan unsur-unsur terakhir yang perlu diperhatikan. Musik dan dekorasi mampu membantu menciptakan citra yang ingin dicapai sebuah kafe.

\section{Metode Penelitian}

Metodologi penelitian adalah kuantitatif dengan mengolah data hasil sebaran kuesioner dan kualitatif dengan observasi serta wawancara. Penyusunan kuesioner berlandaskan teori keterikatan tempat oleh Waxmann (2006). Pedoman wawancara berlandaskan teori kafe sebagai tempat ketiga oleh Tjora dan Scambler (2013). Panduan observasi berlandaskan teori tempat ketiga oleh Oldenburg (1999).

Penentuan kafe sebagai objek penelitian berdasarkan asas kontradiksi. Kafe berada di lingkungan yang padat dan lengang. Kafe yang terpilih adalah Musat di Bandung dan Siloka 2 di Tasikmalaya. Perbedaan kota pada sampel kafe berkaitan dengan kemudahan pengambilan data oleh peneliti yang berada di kota yang berbeda. Kafe Musat di Bandung berdiri di area pertokoan sedangkan Siloka 2 di Tasikmalaya di area tanah lapang.

Pengumpulan data dalam penelitian ini dilakukan dengan cara menyebarkan kuesioner secara daring kepada orang-orang yang pernah berkunjung ke kafe-kafe tersebut. Hal ini dilakukan untuk menilai faktorfaktor keterkaitan tempat antara tingkah laku, perasaan, dan aktivitas pengunjung dengan faktor-faktor statis desain yang ada di dalam kafe. Responden menjawab daftar pertanyaan dan pernyataan kuesioner yang mengacu kepada literatur. Sistem pertanyaan menggunakan skala likert 1-5 dengan 1 sebagai nilai terkecil dan 5 sebagai nilai terbesar. Setelah data terkumpul, seluruh nilai tersebut dirata-ratakan sehingga mendapat nilai akhir dari ketiga kafe.Wawancara secara mendalam dilakukan dengan barista atau pemilik kafe. Pertanyaan bertujuan untuk menghimpun data-data yang hanya dimiliki oleh pemilik/barista. Temuan wawancara dengan pihak kafe dilakukan untuk menyimpulkan tujuan berdiri dan citra tempat ketiga kafe.

Analisis data dilakukan dengan mengolah hasil kuesioner, menyimpulkan hasil wawancara, dan meninjau hasil dokumentasi dan observasi. Hasil kuesioner dan kesimpulan wawancara digunakan untuk menentukan citra kafe sebagai tempat ketiga. Selain itu, hasil kuesioner pun digunakan untuk meninjau unsur keterikatan tempat. Hasil temuan terkait citra tempat ketiga dan keterikatan tempat pada dua objek penelitian dibandingkan untuk selanjutnya dirumuskan kesimpulan.

\section{Hasil dan Pembahasan}

\subsection{Identifikasi Citra Kafe Musat sebagai Tempat Ketiga}

Musat didirikan pertama kali pada tahun 2018 oleh dua orang sahabat-Danu dan Musa-yang berasal dari Bandung. Nama Musat sendiri berasal dari kata Memusat yang menurut KBBI diartikan sebagai keadaan menuju satu titik pertemuan.

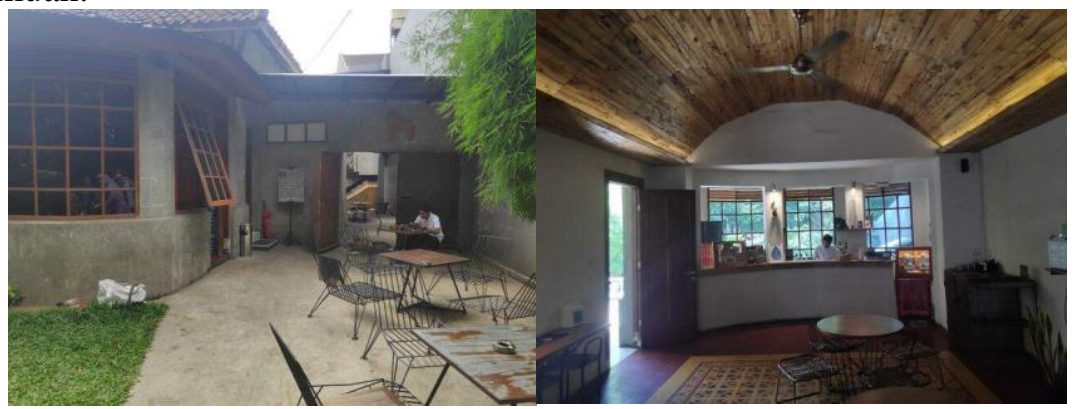

Gambar 2. Keterikatan Tempat yang Dibuat Melalui Muka depan Musat Setelah Memasuki Gerbang (kiri) dan Area Entrance Dalam Kafe yang Langsung Disambut Dengan Barista di Bar (kanan).

(Sumber: Dokumen Peneliti, 2020) 
Berbagai menu dijual di kafe ini, mulai dari berbagai jenis minuman olahan kopi, berbagai jenis minuman berbasis non-kopi, hingga berbagai jenis makanan ringan dan makanan berat. Pengunjung Musat umumnya adalah generasi $\mathrm{Y}$ dan $\mathrm{Z}$ dengan rentang umur 17-25 tahun dengan durasi tinggal mayoritas 1-3 jam. Pengunjung kafe musat hampir merata antara jumlah laki-laki dan perempuan.
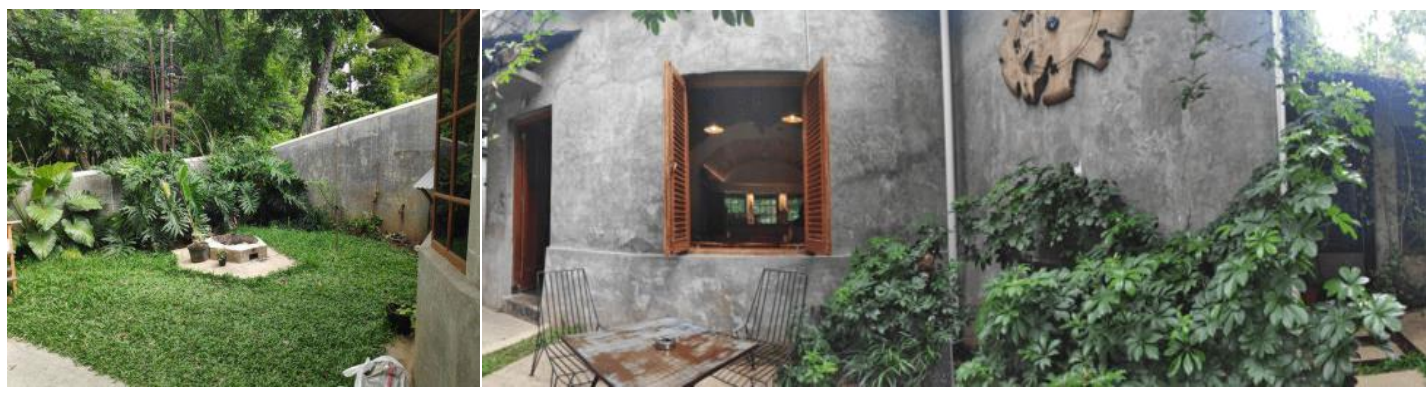

Gambar 3. Citra Tempat Ketiga Kafe dengan Desain Fire Place yang Berada di Area Depan Kafe (kiri) dan Area Luar Kafe yang Didominasi Oleh Dinding Ekspos Tanpa Finishing dan Alam (kanan).

(Sumber: Dokumen Peneliti, 2020)

Berawal dari keinginan Danu dan Musa memiliki tongkrongan dengan konsep forest in urban, citra tempat ketiga kafe ini adalah sebagai tempat bagi orang-orang berkumpul untuk sekadar nongkrong, bergaul bersama teman sejawat atau mengerjakan tugas dan berkolaborasi. Gagasan konsep tersebut menurut pemilik saat diwawancara berlatar belakang pemilik kafe yang dahulu merupakan anggota pecinta alam saat SMA. Konsep desain mendukung citra dengan pengolahan furnitur sosiopetal dan pemilihan gaya bahasa desain yang menjukstaposisi dua hal kontras yaitu industrial dengan alam. Hal tersebut membuat Kafe Musat dapat menjadi wahana untuk orang-orang berkumpul bersama tertawa maupun untuk melakukan diskusi berkolaborasi.

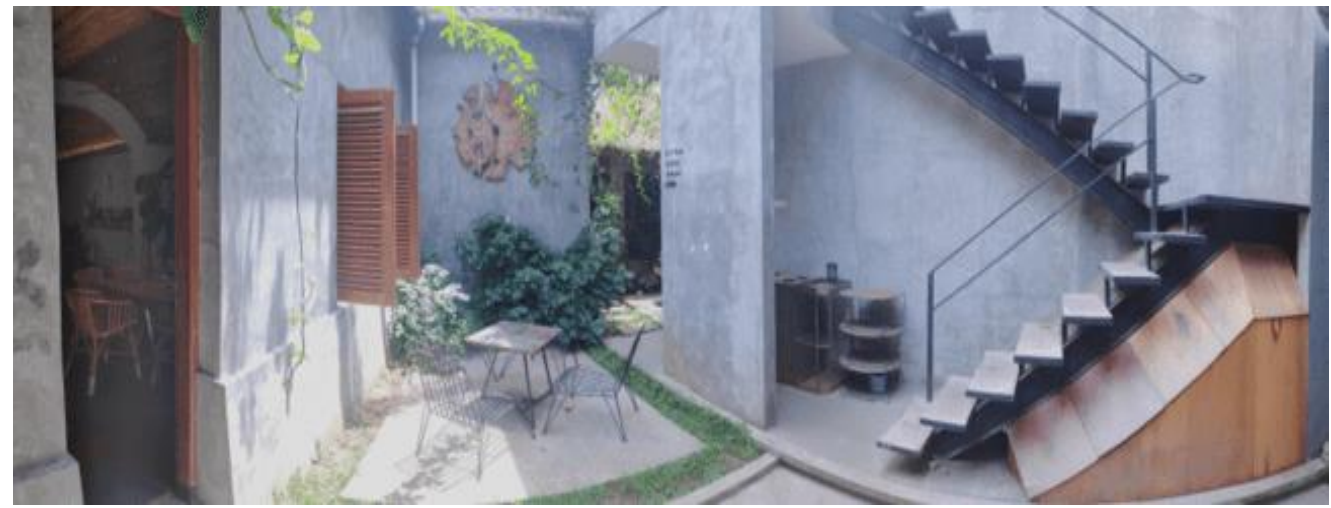

Gambar 4. Area Tempat Duduk di Luar Kafe dengan Posisi Tempat Duduk Sosiopetal Mendukung Citra Tempat Ketiga Kafe.

(Sumber: Dokumen Peneliti, 2020)

Menurut pemilik, kafe tersebut mulanya merupakan rumah belanda yang di-retouch sehingga tata letak posisi dari furnitur-furnitur disesuaikan dengan eksisting kafe. Kafe ini terdiri dari dua massa bangunan. Bangunan depan yang merupakan area dalam kafe dan bangunan kedua merupakan retail yang disewakan beserta musholla. Desain yang dilakukan Kafe Musat adalah penggunaan langit-langit yang sudah ada sebelumnya hanya ditambahkan material penutup bilah-bilah kayu untuk memperhangat kondisi interior kafe juga bentuk muka bangunan yang bersegi-banyak dipertahankan ke desain tambahan, seperti di meja bar, archus di langit-langit dan langit-langit. Posisi bukaan jendela yang sudah ada dari sebelumnya juga dipertahankan sehingga menjadi vista dan penghubung visual antara area dalam yang menekankan kehangatan nuansa dalam rumah dengan dominasi kayu dengan area luar yang mayoritas menggunakan furnitur logam dan dinding ekspos tanpa finishing.

\subsection{Identifikasi Citra Kafe Siloka 2 sebagai Tempat Ketiga}

Kape Siloka 2 merupakan cabang kedua dari waralaba bisnis kedai kopi milik Arif Hidayat Putra yang pertama kali didirikan 4 Juli 2019. Kafe ini dibangun di sebuah lahan terbuka di Jl. Brigjen Wasita Kusumah, Indihiang, Tasikmalaya. 


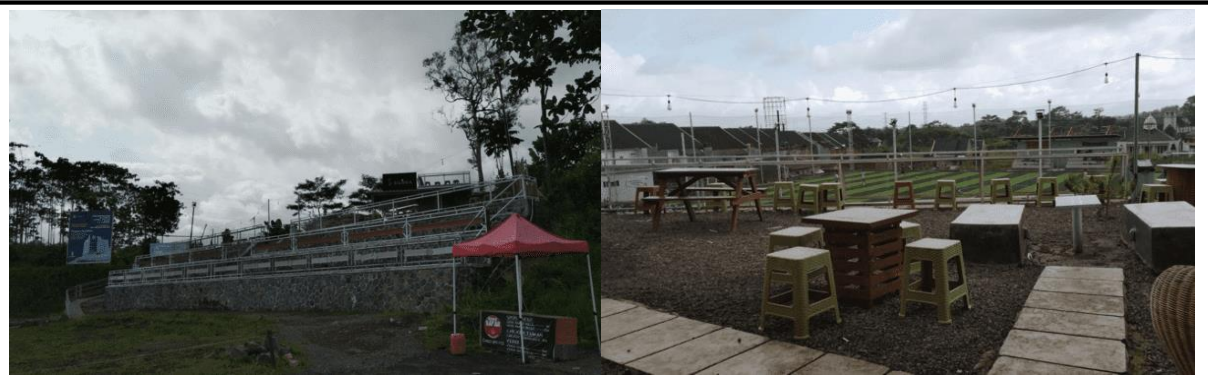

Gambar 5. Citra Tempat Ketiga Kafe Siloka 2 sebagai Tempat Hiburan dengan Pertunjukan Futsal di Hadapannya.

(Sumber: Dokumen Peneliti, 2020)

Kafe menghadap ke arah penyewaan lapangan futsal sejauh 20 meter dengan perbedaan elevasi 3 meter lebih. Pengunjung kafe Siloka umumnya adalah generasi $\mathrm{Y}$ dan $\mathrm{Z}$ yang berusia 17-25 tahun. Durasi pengunjung singgah di kafe selama 1-3 jam. Mayoritas pengunjung kafe adalah pria.

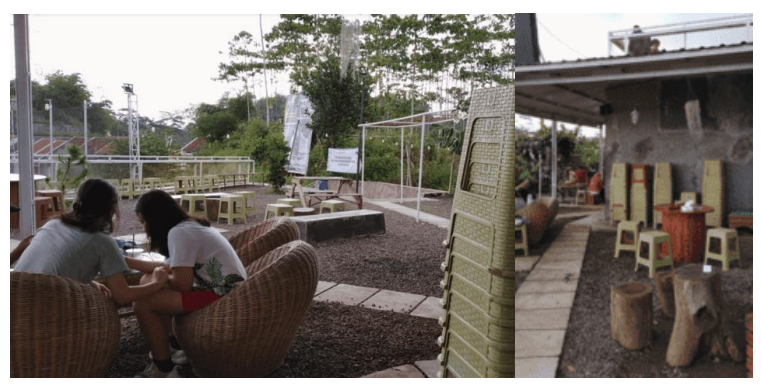

Gambar 6. Citra Tempat Ketiga Kafe Siloka 2 sebagai Tempat Berkumpul dan Bergaul.

(Sumber: Dokumen Peneliti, 2020)

Pengunjung memaknai kafe Siloka 2 sebagai tempat berkumpul dan bergaul. Pengguna kafe mendapatkan kebahagiaan, dukungan, dan hiburan dari interaksi sosial bersama teman sejawat. Konsep desain kafe Siloka 2 menunjang tercapainya hal tersebut dengan pengolahan ruang terbuka berpola sosiopetal. Letak tempat duduk dapat memengaruhi tercapainya interaksi sosial. Kafe Siloka 2 menerapkan perletakan tempat duduk yang fleksibel dan didukung oleh pemilihan kursi plastik ringan yang bisa dipindahkah sesuai keinginan pengunjung.

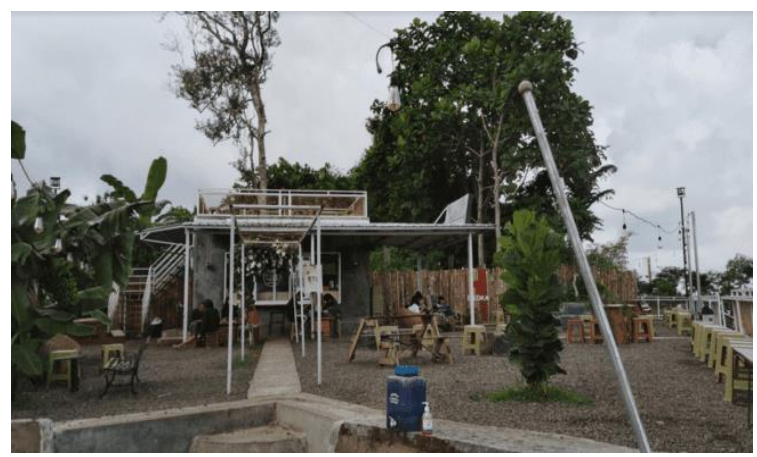

\section{Gambar 7. Konsep Warung Kopi Terbuka dalam Citra Tempat Ketiga Kafe Siloka 2 sebagai Tempat Berkumpul, Bergaul, dan Hiburan.}

(Sumber: Dokumen Peneliti, 2020)

Kafe Siloka 2 sebagai tempat ketiga memiliki citra sebagai tempat berkumpul, bergaul, dan hiburan bagi para pengunjungnya. Respon desain kafe untuk mewadahi dan ikut menunjang citra tersebut adalah dengan penerapan konsep kafe sebagai warung kopi terbuka dengan elemen pertunjukan di sekitar tapak. Kafe Siloka 2 hanya memiliki satu massa bangunan berukuran kurang lebih $30 \mathrm{~m}^{2}$ yang berfungsi sebagai kasir, dapur, ruang karyawan, dan toilet. Bagian atap massa bangunan ini dijadikan sebagai area tempat duduk pengunjung yang dapat diakses dengan tangga di samping kiri massa. Pengunjung di area ini dapat pemandangan sekitar dan permainan sepak bola yang berada di depan kafe Siloka 2 . 


\subsection{Keterikatan Tempat Pengguna terhadap Kafe Musat}

Faktor sosial yang paling memengaruhi keterkaitan tempat pengguna adalah opportunity to linger. Hal ini sejalan dengan hasil wawancara dengan pemilik yang menyebutkan bahwa Musat memang menyambut dan merencanakan hal tersebut terjadi. Keterkaitan tempat yang membuat pengunjung ingin berdiam lama didukung dari faktor fisik seperti aspek kebersihan, pemilihan vegetasi dan pengaturan vista, pemilihan musik yang diputar, hingga dekorasi, dan pencahayaan

Tabel 1. Analisis Keterkaitan Tempat Faktor Sosial berdasarkan Kuesioner

\begin{tabular}{|c|l|l|l|l|l|l|}
\hline $\mathbf{n}$ & $\begin{array}{c}\text { Opportunity to } \\
\text { Linger }\end{array}$ & $\begin{array}{c}\text { Feelings of } \\
\text { Ownership }\end{array}$ & $\begin{array}{c}\text { Trust, Respect } \\
\text { \& Anonimity }\end{array}$ & $\begin{array}{c}\text { Productivity \& Personal } \\
\text { Growth }\end{array}$ & $\begin{array}{c}\text { Social Beings and Familiar } \\
\text { Strangers }\end{array}$ & Support \\
\hline 58 & 4,4 & 4,2 & 4,1 & 3,7 & 3,5 & 2,1 \\
\hline
\end{tabular}

$*(1=$ Nilai Terendah; $5=$ Nilai Tertinggi)

Sumber: Kuesioner Pribadi, 2020

Tabel 2. Analisis Keterkaitan Tempat Faktor Fisik berdasarkan Kuesioner

\begin{tabular}{|c|c|c|c|c|c|c|c|c|}
\hline $\mathbf{n}$ & $\begin{array}{c}\text { Clean- } \\
\text { liness }\end{array}$ & Aroma & $\begin{array}{c}\text { Adequate } \\
\text { Lighting }\end{array}$ & $\begin{array}{c}\text { Access to } \\
\text { Natural Light }\end{array}$ & $\begin{array}{c}\text { Comfortable } \\
\text { Furniture }\end{array}$ & $\begin{array}{c}\text { Appealing } \\
\text { Views }\end{array}$ & $\begin{array}{c}\text { Appealing } \\
\text { Music }\end{array}$ & $\begin{array}{c}\text { Appealing } \\
\text { Decor }\end{array}$ \\
\hline 58 & 4,5 & 3,9 & 4,1 & 4,0 & 3,9 & 4,2 & 4,2 & 4,2 \\
\hline
\end{tabular}

$*(1=$ Nilai Terendah; $5=$ Nilai Tertinggi $)$

Sumber: Kuesioner Penelitian, 2020

Penggunaan sistem self pick-up menu yang sudah dipesan membuat intensitas interaksi antara barista dengan pengunjung semakin sering terjadi. Sistem self-service dalam hal kebersihan membuat pengunjung memiliki tanggung jawab akan bagian kafe yang mereka tempati. Alat makan yang sudah kotor disimpan ke tray yang sudah disediakan oleh pemilik kafe. Penggunaan lima buah wadah tempat sampah yang dikategorisasi sesuai dengan jenis limbah yang diproduksi musat juga menjadi aspek pendukung. Selain itu material terpilih seperti dinding dan kebanyakan lantai hanya dengan penyelesaian semen membuat pembersihan area kafe tidak menghabiskan banyak waktu. Dua suasana yang berbeda antara ruang luar yang industrialis dan hijau dengan ruang dalam yang intim dan hangat membuat dua pilihan kontras untuk pengunjung. Pemilihan faktor-faktor penunjang yang terkurasi sesuai dengan target pasar dari pengunjung kafe membuat konsep dan keseluruhan eksekusi menjadi satu kesatuan yang saling menopang. Hal-hal tersebut menjadi faktor fisik pendukung pengunjung betah berlama-lama diam di Kafe Musat.

\subsection{Keterikatan Tempat Pengguna terhadap Kafe Siloka 2}

Faktor sosial yang paling membuat pengunjung merasa terikat terhadap Kafe Siloka 2 adalah kesempatan untuk berdiam lama (opportunity to linger) karena kafe dinilai nyaman. Kenyamanan kafe dipengaruhi oleh faktor fisik yaitu kebersihan, pencahayaan alami, dan pemandangan.

Tabel 3. Analisis Keterkaitan Tempat Faktor Sosial berdasarkan Kuesioner

\begin{tabular}{|c|c|c|c|c|c|c|}
\hline $\mathbf{n}$ & $\begin{array}{c}\text { Opportunity to } \\
\text { Linger }\end{array}$ & $\begin{array}{c}\text { Feelings of } \\
\text { Ownership }\end{array}$ & $\begin{array}{c}\text { Trust, Respect } \\
\text { \& Anonimity }\end{array}$ & $\begin{array}{c}\text { Productivity \& Personal } \\
\text { Growth }\end{array}$ & $\begin{array}{c}\text { Social Beings and } \\
\text { Familiar Strangers }\end{array}$ & Support \\
\hline 49 & 4.02 & 3.84 & 3.61 & 3.16 & 3.45 & 2.8 \\
\hline
\end{tabular}

$*(1=$ Nilai Terendah; $5=$ Nilai Tertinggi $)$

Sumber: Kuesioner Pribadi, 2020

Tabel 4. Analisis Keterkaitan Tempat Faktor Fisik berdasarkan Kuesioner

\begin{tabular}{|c|c|c|c|c|c|c|c|c|}
\hline $\mathbf{n}$ & $\begin{array}{c}\text { Clean- } \\
\text { liness }\end{array}$ & Aroma & $\begin{array}{c}\text { Adequate } \\
\text { Lighting }\end{array}$ & $\begin{array}{c}\text { Access to } \\
\text { Natural Light }\end{array}$ & $\begin{array}{c}\text { Comfortable } \\
\text { Furniture }\end{array}$ & $\begin{array}{c}\text { Appealing } \\
\text { Views }\end{array}$ & $\begin{array}{c}\text { Appealing } \\
\text { Music }\end{array}$ & $\begin{array}{c}\text { Appealing } \\
\text { Decor }\end{array}$ \\
\hline 49 & 4.12 & 3.78 & 3.92 & 4,37 & 3.6 & 4.14 & 4.06 & 3.59 \\
\hline
\end{tabular}

*(1= Nilai Terendah; $5=$ Nilai Tertinggi)

Sumber: Kuesioner Pribadi, 2020

Penggunaan material pada lantai kafe yang berupa batu kerikil dan jalur pejalan kaki serta area tribun tempat duduk dari plesteran beton membuat kafe mudah dan cepat dibersihkan tanpa harus dipel. Pencahayaan alami kafe menunjang kenyamanan pengunjung karena hampir sebagian besar letak tempat duduk berada di 
area terbuka. Kafe Siloka dua menghadap ke area lapangan futsal sehingga menyuguhkan pemandangan yang tidak biasa bagi para pengunjungnya. Selain itu, kondisi kafe yang dikelilingi oleh vegetasi di bagian timur, utara, dan barat memberikan kesan asri yang dapat menunjang kenyamanan.

\subsection{Pengaruh Hubungan Keterikatan Tempat dan Citra Tempat Ketiga terhadap Desain Kafe Musat}

Kafe yang berlokasi di Jalan Cilaki No. 45, Cihapit, Kota Bandung ini setiap harinya buka pukul 10.00 hingga 24.00 WIB. Namun di kala pandemi jam buka berubah menjadi pukul 08.00-21.00 WIB. Kafe ini memiliki aksesibilitas tinggi dikarenakan lokasinya yang berada di salah satu sentra kuliner Kota Bandung yaitu Jalan Cilaki.

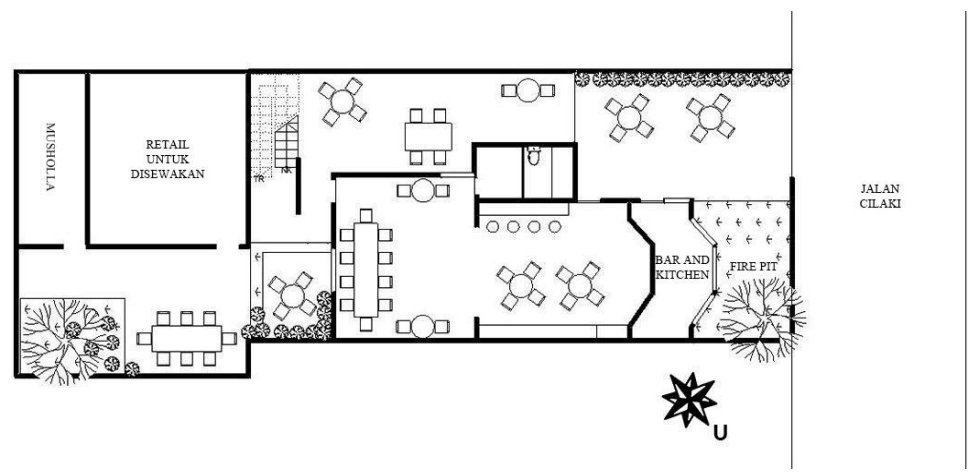

Gambar 8. Denah Musat.

(Sumber: Dokumen Peneliti, 2020)

Untuk mencapai kafe ini dapat diakses melalui jalan kaki, kendaraan pribadi, maupun ojek online. Area depan kafe di Jalan Cilaki menyediakan parkir baik untuk kendaraan roda dua maupun roda empat. Kafe ini memiliki konsep forest in urban yang memasukkan unsur alam ke dalam budaya penggunanya dan elemen desain baik arsitektur, interior maupun produk.

Desain logo Musat menggunakan jenis font yang kaku menggambarkan urbanisme dan karakter gorila yang merupakan intepretasi ulang dari film Tarzan. Selain untuk mengangkat konsep forest in urban, jukstaposisi antara alam dan urban bertujuan untuk menjadikan desain kafe yang dapat menerima dan menyambut pengunjung. Jukstaposisi tersebut tak hanya pada desain produk berupa logo, tetapi juga keseluruhan desain arsitektur. Hal tersebut terbukti dari durasi responden tinggal di Musat dalam sekali kunjungan bervariasi, 13 responden selama 1-2 jam, 29 responden selama 2-3 jam, dan 14 responden selama lebih dari 3 jam. Lokasi pintu masuk (Gambar 8) yang berada di dekat dengan barista (bar and kitchen), membuat pengawasan dan penyambutan pengunjung lebih mudah dan aksesibel.

\subsection{Pengaruh Hubungan Keterikatan Tempat dan Citra Tempat Ketiga terhadap Desain Kafe Siloka 2}

Sirkulasi pengunjung kafe cukup baik karena jalan bagi pengunjung memiliki perbedaan material yaitu dengan plesteran beton. Denah kafe yang berbentuk open plan memungkinkan terjadinya interaksi sosial antar pengunjung.

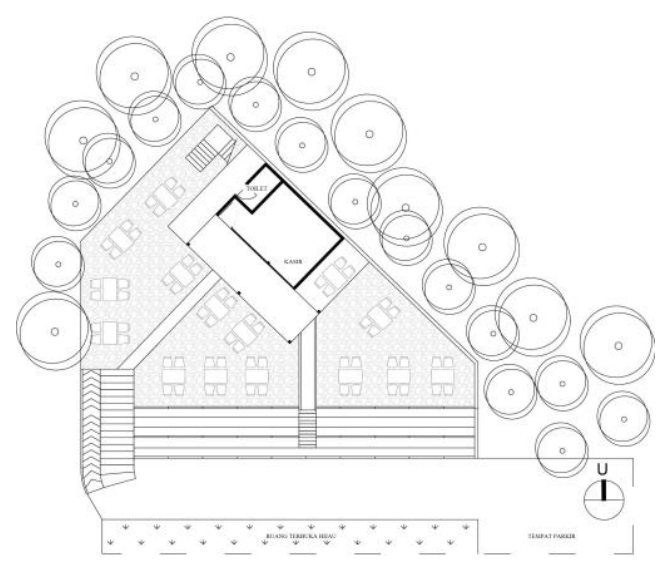

Gambar 9. Denah Kafe Kopi Siloka 2.

(Sumber: Dokumen Peneliti, 2020) 
Selain itu, pemilihan desain tempat duduk yang mudah dipindahkan di area kafe bermaterial kerikil pun dapat mendukung terbentuknya pola ruang sosiopetal. Pola ruang ini dapat merangsang terjadinya konversasi antar pengunjung. Selain itu, pemandangan sekitar tapak yang asri turut menunjang terciptanya percakapan yang santai dan menyenangkan.

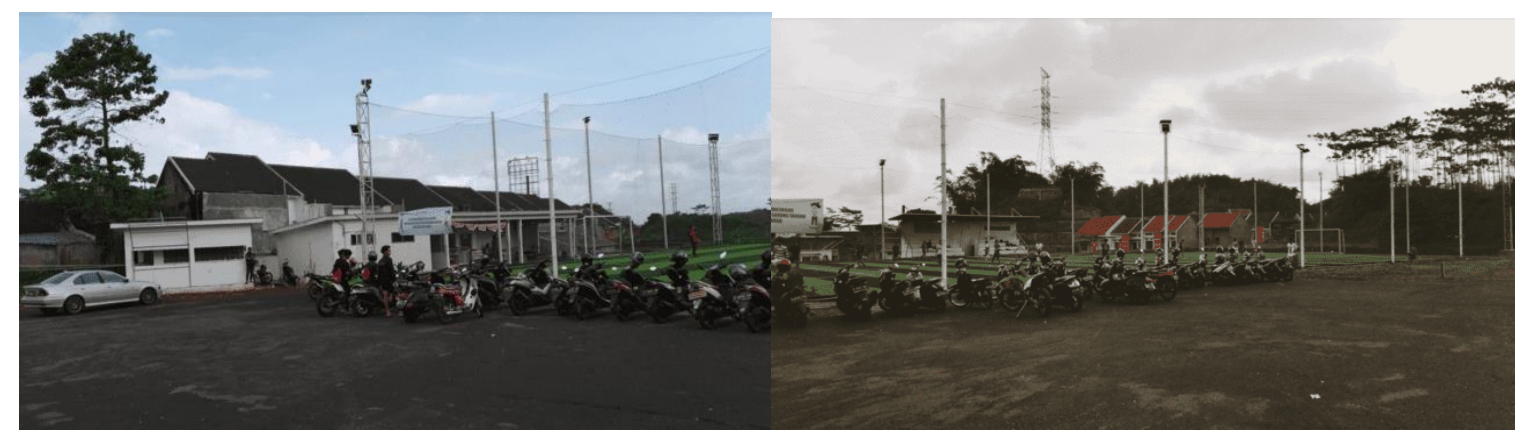

Gambar 10. Area Parkir di Kafe Siloka 2. (Sumber: Dokumen Peneliti, 2020)

Meskipun area kafe ini memiliki dari jalan raya, tetapi kafe Siloka 2 dan bisnis penyewaan tempat futsal menyediakan ruang parkir berpasir yang cukup luas. Komunitas pemain bola yang menyewa tempat futsal tak jarang ikut singgah pula di Siloka sehingga kafe ini mempunyai pengunjung langganan. Konsep warung kopi dengan halaman luas mendorong terciptanya inklusivitas desain. Sehingga, kafe Siloke 2 terkesan sederhana dan dan bisa didatangi oleh berbagai kalangan. Pemaknaan kafe bagi pengunjung adalah sebagai tempat bergaul dan hiburan. Pemaknaan ini memengaruhi keterikatan tempat terhadap kafe.

Tabel 7. Tabulasi Data

\begin{tabular}{|c|c|c|}
\hline Nama Kafe & Musat & Kopi Siloka 2 \\
\hline \multicolumn{3}{|c|}{ Identifikasi Citra Kafe sebagai Tempat Ketiga } \\
\hline Citra Kafe & $\begin{array}{l}\text { Kafe sebagai tongkrongan dan } \\
\text { kolaborasi }\end{array}$ & Kafe sebagai tempat bergaul dan hiburan. \\
\hline Konsep Desain & $\begin{array}{l}\text { Kafe sebagai Forest in urban } \\
\text { dengan menyentuh desain dan } \\
\text { budaya yang mementingkan } \\
\text { dan memasukkan unsur alam. }\end{array}$ & $\begin{array}{l}\text { Kafe sebagai warung kopi terbuka dengan elemen pertunjukan } \\
\text { di sekitar tapak. }\end{array}$ \\
\hline \multicolumn{3}{|c|}{ Pengaruh Keterikatan Tempat Kafe terhadap Citra Tempat Ketiga } \\
\hline Faktor Sosial & 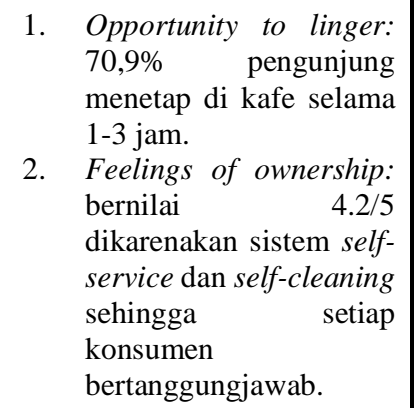 & $\begin{array}{l}\text { 1. Opportunity to linger: } 81,6 \% \text { pengunjung menetap di kafe } \\
\text { selama 1-3 jam. } \\
\text { 2. Feelings of ownership: pengunjung leluasa menggunakan } \\
\text { fasilitas tempat duduk kafe yang disediakan bertumpuk di } \\
\text { tempat tertentu. }\end{array}$ \\
\hline Faktor Fisik & 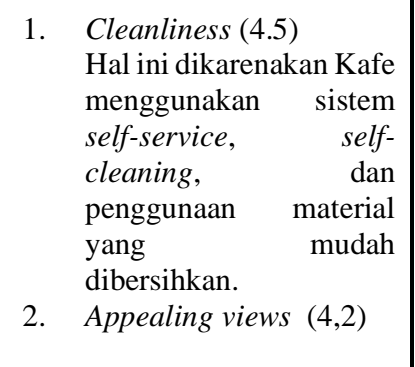 & $\begin{array}{l}\text { 1. Access to natural light (4.37) } \\
\text { Konsep warung kopi dengan halaman terbuka } \\
\text { memungkinkan area kafe mendapatkan pencahayaan } \\
\text { alami yang maksimal. } \\
\text { 2. Appealing views (4.14) } \\
\text { Pemandangan sekitar kafe adalah vegetasi, lapangan sepak } \\
\text { bola, dan permukiman. } \\
\text { 3. Cleanliness (4.12) } \\
\text { Material lantai kafe dari kerikil tidak memerlukan } \\
\text { pemeliharaan khusus. }\end{array}$ \\
\hline
\end{tabular}




\begin{tabular}{|c|c|c|c|}
\hline Nama Kafe & Musat & \multicolumn{2}{|c|}{ Kopi Siloka 2} \\
\hline & $\begin{array}{l}\text { Didukung dengan } \\
\text { konsep forest in urban, } \\
\text { pemilihan vegetasi, dan } \\
\text { penempatan bukaan } \\
\text { ruangan yang menjadi } \\
\text { vista. } \\
\text { 3. Appealing music (4.2) } \\
\text { Merupakan salah satu } \\
\text { faktor yang dinilai baik } \\
\text { dikarenakan musik yang } \\
\text { diputar terkurasi sesuai } \\
\text { target pasaran dan } \\
\text { terkadang ada acara live } \\
\text { music. }\end{array}$ & & \\
\hline \multicolumn{4}{|c|}{ Pengaruh Hubungan Keterikatan Tempat dan Citra Tempat Ketiga terhadap Desain Kafe } \\
\hline Neutral ground & $\begin{array}{l}\text { Sirkulasi kafe menyesuaikan den } \\
\text { pada beberapa bagian dindingn } \\
\text { luar-dalam saling berkomunikas } \\
\text { untuk mengaksesnya. }\end{array}$ & $\begin{array}{l}\text { g yang } \\
\text { ruang } \\
\text { unjung }\end{array}$ & $\begin{array}{l}\text { Sirkulasi dalam kafe cukup } \\
\text { baik karena jalan bagi } \\
\text { pengunjung memiliki } \\
\text { perbedaan material yaitu } \\
\text { dengan plesteran beton. }\end{array}$ \\
\hline $\begin{array}{l}\text { A social leveler or a level- } \\
\text { playing field for participants }\end{array}$ & $\begin{array}{l}\text { Denah kafe yang berbentuk open } \\
\text { interaksi sosial antar pengunjun } \\
\text { dengan area bar menciptakan } \\
\text { pengunjung kafe. }\end{array}$ & $\begin{array}{l}\text { adinya } \\
\text { lekatan } \\
\text { dengan }\end{array}$ & $\begin{array}{l}\text { Denah kafe yang berbentuk } \\
\text { open plan memungkinkan } \\
\text { terjadinya interaksi sosial } \\
\text { antar pengunjung. }\end{array}$ \\
\hline Conversation & $\begin{array}{l}\text { Susunan furnitur di dalam kafe } \\
\text { dua meja yang digunakan seca } \\
\text { dalam dan luar kafe. }\end{array}$ & $\begin{array}{l}\text { erdapat } \\
\text { ble) di }\end{array}$ & $\begin{array}{l}\text { Pemilihan desain tempat } \\
\text { duduk yang mudah } \\
\text { dipindahkan di area kafe } \\
\text { bermaterial kerikil pun dapat } \\
\text { mendukung terbentuknya pola } \\
\text { ruang sosiopetal. Pola ruang } \\
\text { ini dapat merangsang } \\
\text { terjadinya konversasi antar } \\
\text { pengunjung. }\end{array}$ \\
\hline $\begin{array}{l}\text { Good accessibility and } \\
\text { accommodation }\end{array}$ & $\begin{array}{l}\text { Aksesibilitas menuju kafe muda } \\
\text { area pusat kuliner Kota Bandu } \\
\text { menggunakan jalan kaki, ken } \\
\text { online. Juga tersedia parkir kend }\end{array}$ & $\begin{array}{l}\text { dalam } \\
\text { diakses } \\
\text { n ojek } \\
\text { pak. }\end{array}$ & $\begin{array}{l}\text { Penyediaan ruang parkir yang } \\
\text { cukup luas. Pengunjung harus } \\
\text { berjalan sekitar } 10 \text { meter dari } \\
\text { pinggir jalan raya sebelum tiba } \\
\text { di area kafe. }\end{array}$ \\
\hline A low profile & $\begin{array}{l}\text { Entrance kafe yang terkesan } i \\
\text { eksklusif. Desain ini bertujua } \\
\text { perhatian dan kegiatan ke dalam }\end{array}$ & $\begin{array}{r}\text { kesan } \\
\text { pusat }\end{array}$ & $\begin{array}{l}\text { Konsep warung kopi dengan } \\
\text { halaman luas mendorong } \\
\text { terciptanya inklusivitas desain. } \\
\text { Sehingga, kafe Siloke } 2 \\
\text { terkesan sederhana dan dan } \\
\text { bisa didatangi oleh berbagai } \\
\text { kalangan }\end{array}$ \\
\hline Playful mood & $\begin{array}{l}\text { Tujuan kafe yang awalnya seb } \\
\text { terwujud. Kafe digunakan } \\
\text { berdiskusi dengan teman sejawa }\end{array}$ & nyata & $\begin{array}{l}\text { Pemandangan sekitar tapak } \\
\text { yang asri turut menunjang } \\
\text { terciptanya percakapan yang } \\
\text { santai dan menyenangkan } \\
\text { antar pengunjung. }\end{array}$ \\
\hline
\end{tabular}




\section{Kesimpulan}

Berdasarkan penelitian ini, dapat ditarik kesimpulan dan temuan berupa:

1. Citra Kafe Musat sebagai tempat ketiga adalah tempat tongkrongan dan berkolaborasi. Konsep Kafe Musat adalah forest in urban yaitu memadukan material industrial dengan unsur alam. Kebersihan, pemandangan, dan pemilihan musik di dalam kafe membuat pengunjung merasa nyaman sehingga muncul perasaan keterikatan tempat.

2. Citra Kafe Siloka 2 sebagai tempat ketiga adalah tempat untuk berkumpul, bergaul, dan hiburan. Konsep kafe ini adalah warung kopi dengan halaman terbuka. Pencahayaan alami, pemandangan sekitar, dan kebersihan kafe membuat pengunjung merasa nyaman sehingga muncul perasaan keterikatan tempat.

3. Perbandingan pengaruh hubungan keterikatan tempat dan citra tempat ketiga terhadap desain kafe dapat ditinjau dari aspek sirkulasi, denah, pola ruang, aksesibilitas, akomodasi, universalitas, dan impresi.

4. Hubungan antara keterikatan tempat dengan citra kafe sebagai tempat ketiga adalah timbal balik. Semakin tinggi derajat keterikatan tempat, maka semakin baik citra kafe sebagai tempat ketiga.

5. Dengan konsep tempat ketiga, maka pemaknaan arsitektur adalah bersifat timbal balik, elemen-elemen fisik pembentuk tempat menjadi berarti karena menjadi perhatian dari penggunanya.

\section{Referensi}

Ekomadyo, Agus S. (2020). Bandung Kota Kafe: Produksi Ruang Kafe oleh Komunitas Kopi di Kota Paris van Java. Antologi Kota Indonesia \#2.

Ekomadyo, Agus S., \& Riyadi, A. (2020). Design in socio-technical perspective: An actor-Network theory reflection on community project "Kampung Kreatif" in Bandung. Archives of Design Research. https://doi.org/10.15187/adr.2020.05.33.2.19

Ekomadyo, Agus S., Santri, T., \& Riyadi, A. (2018). Reassembling Traditionality and Creativity: A Study of Place as Assemblage in Pasar Cihapit Bandung. SHS Web of Conferences. https://doi.org/10.1051/shsconf/20184107006

Ekomadyo, Agus Suharjono, Santri, T., \& Riyadi, A. (2018). Habitat for Innovative Milieu: A Place-Making Study of University and Start-up Enterprises Relationship. IOP Conference Series: Earth and Environmental Science. https://doi.org/10.1088/1755-1315/152/1/012020

Hariyanto. (2019). Riset TOFFIN: Bisnis Kedai Kopi Makin Menggeliat di 2019. Industry. www.industry.co.id/read/58786/riset-toffin-bisnis-kedai-kopi-makin-menggeliat-di-2019

Hashemnezhad, H., Heidari, A. A., \& Hoseini, P. M. (2013). "Sense of place" and "Place Attachment." International Journal of Architecture and Urban Development.

Holmes, H. (2004). Coffee Shop. SBDCNET San Antonio.

Low, S. M., \& Altman, I. (1992). Place Attachment. In Place Attachment. https://doi.org/10.1007/978-1-46848753-4_1

Lukito, Y. N., \& Xenia, A. P. (2018). Café as third place and the creation of a unique space of interaction in UI Campus. IOP Conference Series: Earth and Environmental Science. https://doi.org/10.1088/1755$1315 / 99 / 1 / 012028$

Oldenburg, R. (1999). The Great Good Place. The Great Good Place.

Permana, A. Y. (2012). Peran Ruang Terbuka Publik di Kawasan Slums dan Squatters sebagai "Ruang Ketiga" (Kasus: Kawasan Bantaran Sungai Cikapundung di Kota Bandung. SEMINAR NASIONAL "Sustainable Urbanism" Adaptasi Perubahan Ruang Perkotaan-Pendekatan Teoritik Dan Praktek, 84-98.

Putra, R. A., \& Ekomadyo, A. S. (2015). INTERPRETASI MAKNA PADA WARUNG KOPI ACEH Studi Kasus: Warung Kopi Solong di Banda Aceh. ATRIUM - Jurnal Arsitektur. https://doi.org/10.21460/atvm.2015.11.1

Robbany, I. M., Atidipta, J. M. P., Ihsanti, S. A., Dzauqiah, V., \& Ekomadyo, A. S. (2020). Tipe Ruang Kreatif di Bandung dan Konteks Pendukungnya. EMARA: Indonesian Journal of Architecture. https://doi.org/10.29080/eija.v5i2.779

Rosenbaum, M. S., Ward, J., Walker, B. A., \& Ostrom, A. L. (2007). A Cup of Coffee With a Dash of Love. Journal of Service Research. https://doi.org/10.1177/1094670507303011

Setiati, G., Santosa, I., \& Syarief, A. (2015). GENDER DAN PLACE ATTACHMENT PADA COFFEE SHOP DI BANDUNG. Jurnal Sosioteknologi. https://doi.org/10.5614/sostek.itbj.2015.14.3.8

Shamai, S. (1991). Sense of place: an empirical measurement. Geoforum. https://doi.org/10.1016/00167185(91)90017-K

Stedman, R. C. (2002). Toward a social psychology of place: Predicting behavior from place-based cognitions, 
attitude, and identity. Environment and Behavior. https://doi.org/10.1177/0013916502034005001

Sugianto, D. (2019). Hasil Riset: Kedai Kopi di RI Bertambah 2.000 dalam 3 Tahun. Detik. finance.detik.com/berita-ekonomi-bisnis/d-4826275/hasil-riset-kedai-kopi-di-ri-bertambah-2000dalam-3-tahun

Sulistiani, M. \& R. D. (2018). Studi Temporalitas Ruang terhadap Place Attachment: Kasus pada Kafe di Koridor Jalan Mayjend Yono Soewoyo, Surabaya. Jurnal EDimensi Arsitektur 2018, 6(1), 409-416.

Susanto, V., Amir, M. A. M., Haqqi, M. A., Ekomadyo, A. S., \& Riska, A. S. (2020). PENGARUH GAYA HIDUP MILENIAL TERHADAP DESAIN ARSITEKTUR KAFE. Vitruvian. https://doi.org/10.22441/vitruvian.2020.v9i2.001

Tjora, A., \& Scambler, G. (2013). Café Society. In Café Society. https://doi.org/10.1057/9781137275936

Waxman, L. (2006). The Coffee shop: Social and physical factors influencing place attachment. Journal of Interior Design. https://doi.org/10.1111/j.1939-1668.2006.tb00530.x

Yuwono, A., \& Ekomadyo, A. S. (2018). Designing Public Library As An Urban Community Place. The 4th Biennale International Conference on Indonesian Architecture and Planning (ICIAP): Design and Planning in the Disruptive Era.

Zuhriyah, D. A. (2019). Industri Kedai Kopi Ditaksir Tumbuh $20 \%$ Tahun Ini. Bisnis. ekonomi.bisnis.com/read/20190822/12/1139918/industri-kedai-kopi-ditaksir-tumbuh-20-tahun-ini 